\title{
TREND OF SCIENTIFIC PRODUCTION ON DIGITAL IMPLANT DENTISTRY (1990-2019): A BIBLIOMETRIC STUDY
}

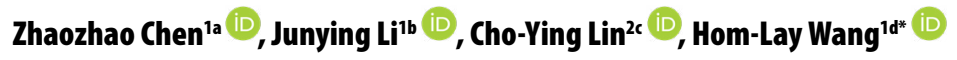 \\ 'Department of Periodontics and Oral Medicine, School of Dentistry, University of Michigan, Ann Arbor, MI, USA \\ 2Department of Periodontics, Chang Gung Memorial Hospital, Taipei, Taiwan \\ aDDS, MS, PhD, Resident; e-mail: zzchen@umich.edu; ORCIDiD: https://orcid.org/0000-0002-2188-1367 \\ bDDS, MS, PhD, Clinical Lecturer; e-mail: junying@umich.edu; ORCIDiD: https://orcid.org/0000-0002-5782-2051 \\ 'DDS, Clinical Lecturer; e-mail: jessicalin1020@gmail.com; ORCIDiD: https://orcid.org/0000-0003-2499-6191 \\ dDDS, MS, PhD, Professor; e-mail: homlay@umich.edu; ORCIDiD: https://orcid.org/0000-0003-4238-1799
}

\section{ABSTRACT}

d.) https://doi.org/10.25241/stomaeduj.2020.7(2).art.6

Background and Objective Digital implantology has become a hot topic in dentistry. The purpose of this paper was to present trends regarding the interests of this field using bibliometric indicators.

Data sources On the basis of articles in the Web of Science database, we performed a quantitative analysis of publications in 1990-2019 on digital implant dentistry.

Data Extraction and Synthesis Excel and VOSviewer were applied to assess the publication trend. A total number of 3680 publications with 57,930 citations up to February 8,2020 , were obtained. More than half (2013; 54.70\%) of the articles were published in the last five years (2015-2019). The United States was in the leading position, with the highest $\mathrm{H}$-index (60), $23.91 \%$ of the publications, and $28.74 \%$ of the total citations. Among the top 10 active authors, eight were from Europe, and the other two were from the United States. The University of Bern (Switzerland) $(101 ; 2.745 \%)$ was the most productive institution, followed by the University of Sao Paulo (Brazil) (89; 2.418\%), and the University of Michigan (United States) (84; 2.283\%). The most active journal in publishing articles related to digital implantology was the Clinical Oral Implant Research (336; 9.13\%), together with the International Journal of Oral \& Maxillofacial Implants (336; 9.13\%). Three of the top 15 funding agencies were well-known implant companies. Digital workflow, digital impression, and $3 \mathrm{D}$ printing are becoming popular research topics. In conclusion, there was a noticeable growth in scientific publications in digital implant dentistry, and most key bibliometric indicators demonstrated its upward trends.

\section{KEYWORDS}

Bibliometrics; Dental Implants; Digital Technologies; Evidence-Based Dentistry; Dental Research.

\section{INTRODUCTION}

Compared to the era of the introduction of dental implants in the 1960s, implant therapy is now highly predictable and has become a widely used treatment modality to replace missing dentition [1]. Along with the continuous technological progress in the treatment planning software, computer-aided design (CAD), and computer-assisted manufacturing technology (CAM), a strong digitalization trend in implant dental medicine is noticed in clinical practice [2]. Evolving from being a merely "surgically driven" to a "restoration-driven" treatment, the concept of implant therapycurrently turns to"computer-assisted" implant placement and even a completely digital workflow $[3,4]$. Together with the increasing use of digital technologies in implant dentistry, research on this topic has grown at an exponential rate, producing increasing numbers of scientific publications every year [5]. The research topics range from pre-clinical to clinical, from surgical to prosthetic related fields. In addition, novel digital equipment such as conebeam computed tomography (CBCT) [6], optical scanner [7,8], magnetic resonance imaging (MRI) [9],

(c) (1) () OPEN ACCESS This is an Open Access article under the CC BY-NC 4.0 license. Peer-Reviewed Article

Citation: Chen Z, Li J, Lin CY, Wang HL. Trend of scientific production on digital implant dentistry (1990-2019): a bibliometric study. Stoma Edu J. 2020;7(2):123-130.

Received: March 08, 2020; Revised: March 20, 2020; Accepted: May 24, 2020; Published: May 26, 2020

*Corresponding author: Professor Hom-Lay Wang, Director, Graduate Periodontics Program, Department of Periodontics and Oral Medicine

University of Michigan School of Dentistry 1011 North University Avenue, Ann Arbor, MI 48109-1078, USA.

Tel: +734 763 3383; Fax: +734 9360374 ; e-mail address: homlay@umich.edu

Copyright: $\odot 2020$ the Editorial Council for the Stomatology Edu Journal 


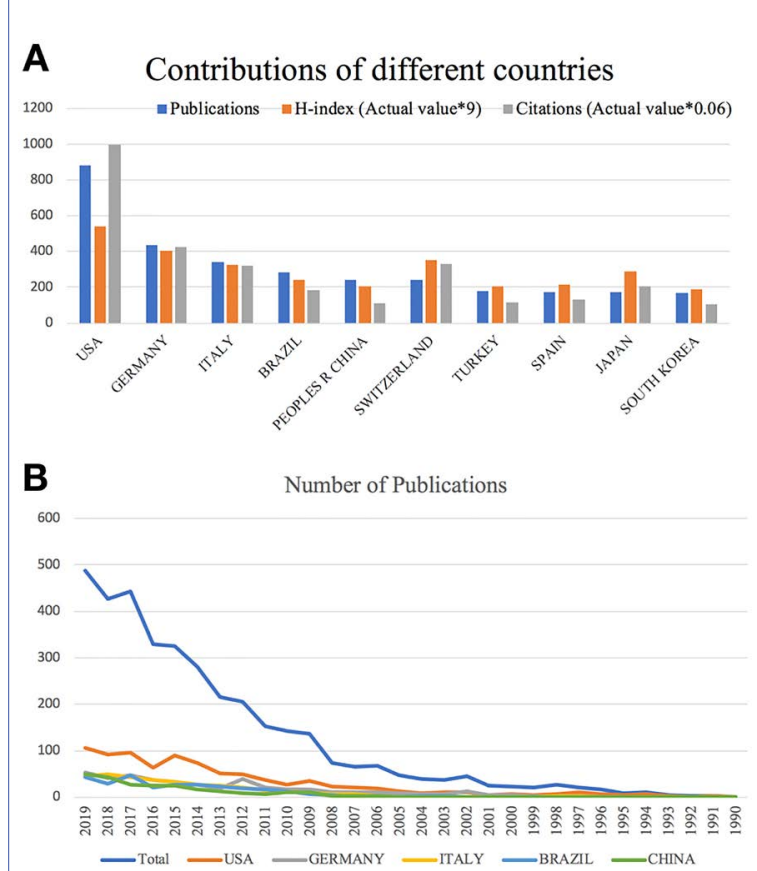

Figure 1. Number of Publications. (A) The number of publications of the top 10 countries and regions; (B) Annual evolution of the scientific production on digital implant dentistry.

and ultrasonography $[10,11]$, are increasingly being tested in research for the assessment of implant treatment outcome. Knowing the trend of the industry is essential for dental practitioners and researchers in this field. With the rapid growth of publications in digital implant dentistry, it is necessary to quantify both results of scientific activity and its impact on the research trend $[12,13]$. In this context, bibliometrics is a useful and objective tool [14].

Bibliometrics is a method of analyzing data from citation indexes. It traces relationships amongst academic journal citations and assesses the trend of a specific field as well as its international scientific impact.

Yet, to our knowledge, the progress of digital implantology so far has not been extensively studied. Therefore, the aim of our study was to present allaround insights on the current state of digital-related implant dentistry.

The distribution of the research publications, affiliations, keywords, and authorships were analyzed to discover the popular topics and to better understand the global trend of research in this field. It is hypothesized that the upward trends in digital implant dentistry will be reflected in the production of quality articles and popular topics.

\section{METHODOLOGY}

\subsection{Literature search strategy}

The literature search was performed in the core collection of Thomson Reuter's Web of Science database, with the manuscript type restricted to articles. The Web of Science is considered the
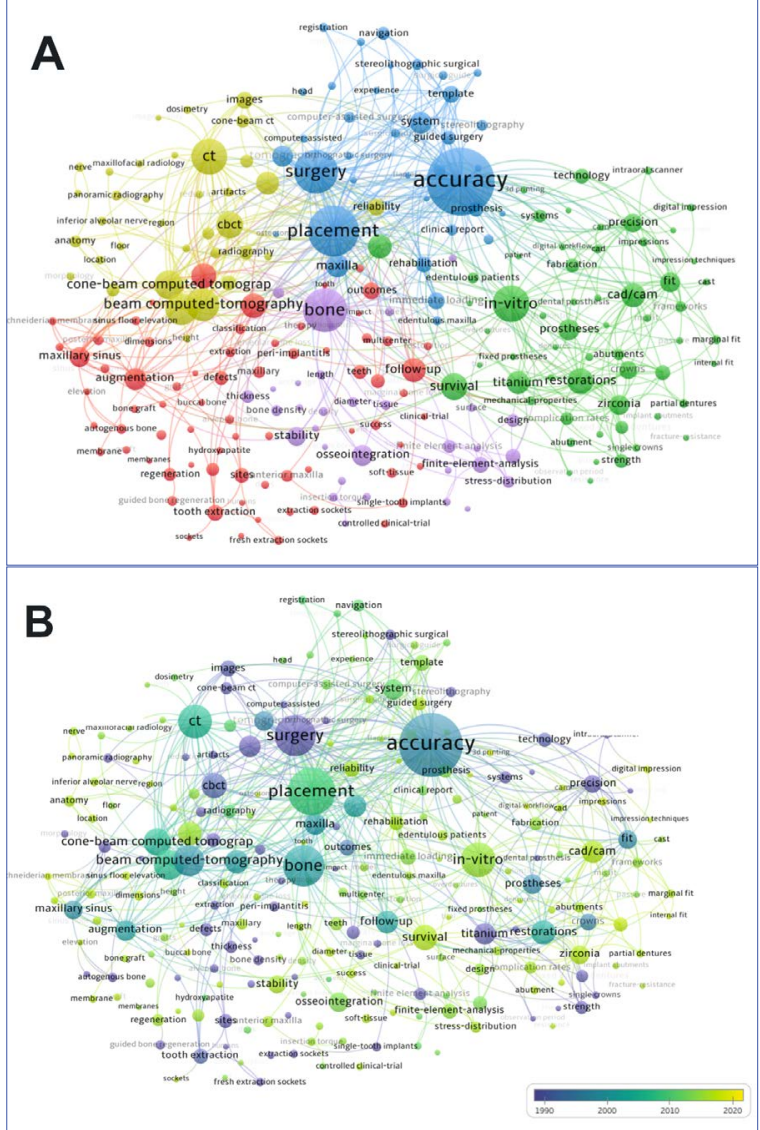

Figure 2. The analysis of keywords (with the occurrence more than 20 times). (A) Based on different clusters; (B) Based on its different average appearing year.

optimum database to perform bibliometric analysis, and it has been applied in many published studies [12-15]. All screenings took place on a single day, February 8,2020 , with an attempt to eliminate any change in the number of publications and citations. The search strategy was: ((TS=)(dental implant* OR implant dentistry* OR dental implantology OR oral implant) ANDTS $=$ (digital ${ }^{*}$ OR digital technologies $O R$ digital workflow OR computer OR computer-guided OR computer-aided OR computer-assisted OR CAD/ CAM OR intraoral scan OR intraoral scanner OR cone beam OR CBCT)) AND LANGUAGE: (English), and timespan for publication was set as 1990-2019.

\subsection{Data collection}

The basic characteristics of selected publications were obtained from the Web of Science by its intrinsic tool Clarivate Analytics.

Data related to publication years, countries/regions, authors, institutions, journals, funding agencies, and citations were exported as Excel files for tabulation.

All journals' impact factor (IF) were retrieved from the Journal Citation Reports of 2019.

$\mathrm{n}$ an attempt to evaluate both the productivity and citations of the publications, the $\mathrm{H}$-index was used, which indicates that a scholar (or country or organization) has published $\mathrm{H}$ papers and each of which has been cited in other publications at least $\mathrm{H}$ times [16]. 
ITable 1. The most productive authors (top 10) with the publications related to digital implant dentistry.

\begin{tabular}{|l|l|l|c|c|c|c|}
\hline \multicolumn{1}{|c|}{ Author } & \multicolumn{1}{|c|}{ Country } & \multicolumn{1}{c|}{ Affiliation } & Docs & $\begin{array}{c}\text { \% of } \\
\mathbf{3 6 8 0}\end{array}$ & Citations & H-index \\
\hline Jacobs R. & Belgium & Catholic University of Leuven & 60 & 1.630 & 2245 & 25 \\
\hline Wang HL. & United States & University of Michigan & 54 & 1.467 & 940 & 19 \\
\hline Bornstein MM. & Switzerland & University of Bern & 33 & 0.897 & 984 & 16 \\
\hline Wismeijer D. & Netherlands & $\begin{array}{l}\text { Academisch Centrum Tandheelkunde } \\
\text { Amsterdam (ACTA) }\end{array}$ & 33 & 0.897 & 981 & 18 \\
\hline Quirynen M. & Belgium & Catholic University of Leuven & 32 & 0.870 & 1207 & 17 \\
\hline Hammerle CHF. & Switzerland & University of Zurich & 29 & 0.788 & 869 & 16 \\
\hline Buser D. & Switzerland & University of Bern & 26 & 0.707 & 1441 & 17 \\
\hline Chan HL. & United States & University of Michigan & 26 & 0.707 & 388 & 12 \\
\hline Jung RE. & Switzerland & University of Zurich & 25 & 0.679 & 769 & 12 \\
\hline Bragger U. & Switzerland & University of Bern & 0.652 & 666 & 16 \\
\hline
\end{tabular}

ITable 2. Top 10 organizations with the most publications related to digital implant dentistry.

\begin{tabular}{|l|l|l|l|l|l|}
\hline Organization & Country & Docs & \% of 3680 & Citations & H-index \\
\hline University of Bern & Switzerland & 101 & 2.745 & 36 & 4504 \\
\hline University of Sao Paulo & Brazil & 89 & 2.418 & 17 & 1319 \\
\hline University of Michigan & United States & 84 & 2.283 & 20 & 1550 \\
\hline University of Zurich & Switzerland & 79 & 2.147 & 21 & 1673 \\
\hline Catholic University of Leuven & Belgium & 59 & 1.603 & 22 & 1976 \\
\hline King Saud University & Saudi Arabia & 55 & 1.495 & 11 & 390 \\
\hline Harvard University & United States & 48 & 1.304 & 23 & 1356 \\
\hline Seoul National University & Korean & 44 & 1.196 & 14 & 512 \\
\hline Yonsei University & Korean & 42 & 1.141 & 10 & 339 \\
\hline University of Geneva & Switzerland & 41 & 1.114 & 16 & 687 \\
\hline
\end{tabular}

\subsection{Statistical analysis}

The data were imported into a java program VOSviewer (version 1.6.8; Leiden University, Leiden, Netherlands). This software was used to visualize a term map analyzing keywords from the extracted data. The data were then analyzed by using the "Create Map" function.

The type of analysis was chosen as "Co-occurrence" and the unit of analysis was set as "All keywords". Only keywords that had the occurrence number more than 20 were displayed. Redundant keywords like "dental implant" and "dentistry" were removed.

Thereafter, a keyword map was generated by the software. For each keyword, the size of the node indicates its frequency of occurrence in the included publications, and larger size represents a higher frequency of occurrence.

In network visualization mode, keywords that frequently occurred together were marked as the same color.

In overlay visualization mode, different colors were used to mark the average publication year of the keywords. [17].

\section{RESULTS}

\subsection{Growth of publications}

In total, 3680 documents published between 19902019 were included. The highest number of articles was published in 2019 with a total number of 448 (13.26\%). More than half $(2013,54.70 \%)$ of the papers were published in the last five years (2015-2019). The total trend and the annual number of documents are shown in Fig. 1. The United States was the most productive country with 880 (23.91\%) publications, followed by Germany $(434 ; 11.79 \%)$ and Italy $(342$; $9.29 \%)$.

\subsection{Distribution of most productive organizations,} journals and funding agencies

Articles from top 10 organizations accounted for $17.45 \%$ of all publications in this field. The University of Bern published the highest number of studies with a total number of 101 (2.745\% of all publications). In the list of the top 10 organizations, three were from Switzerland, two were from the United States, two were from Korea, the rest three were from Brazil, 
ITable 3. The most productive journals on digital implant dentistry.

\begin{tabular}{|l|c|c|c|c|}
\hline Journals & Country & $\begin{array}{c}\text { IF } \\
\mathbf{2 0 1 8}\end{array}$ & Docs & \% of 679 \\
\hline Clinical Oral Implants Research & Denmark & 3.825 & 336 & 9.130 \\
\hline International Journal of Oral \& Maxillofacial Implants & United States & 1.734 & 336 & 9.130 \\
\hline Journal of Prosthetic Dentistry & United States & 2.787 & 190 & 5.163 \\
\hline Clinical Implant Dentistry and Related Research & United States & 3.212 & 181 & 4.918 \\
\hline Journal of Oral and Maxillofacial Surgery & United States & 1.781 & 146 & 3.967 \\
\hline Implant Dentistry & United States & 1.214 & 108 & 2.935 \\
\hline Dentomaxillofacial Radiology & England & 1.525 & 84 & 2.283 \\
\hline Journal of Oral Implantology & United States & 1.062 & 83 & 2.255 \\
\hline International Journal of Periodontal and Restorative Dentistry & United States & 1.228 & 74 & 2.011 \\
\hline
\end{tabular}

Belgium, and Saudi Arabia (Table 2). The top 10 journals publishing the most articles are shown in Table 3. There were 1611 papers published in these journals $(43.78 \%$ of all publications). Clinical Oral Implants Research (IF=3.825, 2018; 336 articles) and International Journal of Oral \& Maxillofacial Implants (IF $=1.734,2018 ; 336$ articles) ranked first, followed by the Journal of Prosthetic Dentistry (IF=2.787, 2018; 190 articles). Among these studies, 1109 out of 3680 (30.14\%) were supported by funding agencies. The top 15 funding agencies are presented in Table 4, with four based in the United States, four in Switzerland, and three in Brazil. NIH in the United States endorsed 81 studies (ranked 1st, 2.201\%), followed by National Natural Science Foundation in China (68 studies, $1.848 \%$ ), and Coordination for the Improvement of Higher Education Personnel (CAPES) in Brazil (48 studies, 1.304\%). Furthermore, implant companies showed great contributions to the development of digital implant dentistry and occupied three of the top 15 funding agencies.

\subsection{Highly contributive authors publishing digital implant dentistry research}

The 3680 documents were authored by 10,598 different authors. The 10 most productive authors are listed in Table 1. The most productive was Jacobs R. $(n=60$, citations $=2245)$ from the Catholic University of Leuven (Belgium), followed by Wang HL. ( $n=54$, citations=1467) from the University of Michigan (United States), and Bornstein MM. $(n=33$, citations $=984)$ from the University of Bern (Switzerland). Five of the top 10 productive authors came from Switzerland, followed by two from the United States, two from Belgium, and one from the Netherlands.

\subsection{Hotspot analysis}

All keywords were extracted from the title/abstract of 3680 articles and then analyzed by VOSviewer software. Keywords, with an occurrence of more than 20 times, were included in the map (Fig. 2) and were stratified into five clusters: cluster 1 (treatment outcome; Fig. 2A, left, in red), cluster 2 (accuracy of digital technology; Fig. 2A, right, in green), cluster 3 (implant planning and placement; Fig. 2A, up, in blue), and cluster 4 (radiograph and anatomy; Fig. $2 \mathrm{~A}$, left, in yellow), and cluster 5 (implant stability and biomechanics; Fig. 2A, middle, in purple). In the cluster 1 , the frequently used keywords were "reconstruction" (162 times), and "implant placement" (161 times), and "follow-up" (152 times). The most frequent keywords in the second cluster were, "invitro" (264 times), "restorations" (166 times), and "CAD/CAM" (147 times). In cluster 3, "accuracy" (586 times), "placement" (400 times), and "surgery" (332 times) were the most frequent keywords. "CT" (251 times), and "cone beam computed tomography" (221 times) were the most frequent keywords in cluster 4. In cluster 5, "bone" (329 times), "osseointegration" (126 times), and "stability" (113 times) were the top 3 frequently used keywords. Based on its different average appearing year, VOSviewer marked each keyword with different colors (Fig. 2B). Keywords in yellow appeared later than those in green and blue. In cluster 1, the newest keywords were "Schneiderian membrane" (34 times) which has an average publication year of 2016, "dimensions" (51 times, 2016), and "floor elevation" (36 times, 2016). In cluster 2, the new focus of "accuracy of digital technology" were "3d printing" (29 times, 2017), "digital impression" (36 times, 2017), and "digital workflow" (26 times, 2017). As for the third cluster, the new focus of "implant planning and placement" was "guided surgery" (74 times) with an average publication year of 2015. In the fourth cluster, the newest keyword was "mental foramen" (32 times, 2015), "inferior alveolar nerve" (45 times, 2015), and "location" (44 times, 2015). In the fifth cluster, "stability" (113 times, 2015) was a relatively new keyword.

\subsection{Characteristics of top 10 articles in digital implant dentistry}

Among all 3680 publications ( 57,980 citations), top 10 cited articles (Table 5) have 2,378 citations (22.19\%). The paper "Bone healing and soft tissue contour 
ITable 4. The top 15 funding-related agencies in digital implantology

\begin{tabular}{|l|c|c|c|}
\hline Funding agency & Country & N & $\%$ of $\mathbf{3 6 8 0}$ \\
\hline National Institutes of Health (NIH) & United States & 81 & 2.201 \\
\hline National Natural Science Foundation of China & China & 68 & 1.848 \\
\hline Coordination for the Improvement of Higher Education Personnel (CAPES) & Brazil & 48 & 1.304 \\
\hline The Department of Health and Human Services (HHS) & United States & 46 & 1.250 \\
\hline Sao Paulo Research Foundation (FAPESP) & Brazil & 43 & 1.168 \\
\hline The Brazilian National Council for Scientific and Technological Development (CNPq) & Brazil & 41 & 1.114 \\
\hline Dentsply & United States & 34 & 0.924 \\
\hline Noble Biotech & Switzerland & 32 & 0.870 \\
\hline ITI Foundation & Switzerland & 32 & 0.870 \\
\hline Ministry Education, Culture, Sports, Science Technology (MEXT) in Japan & Japan & 31 & 0.842 \\
\hline University of Michigan & United States & 30 & 0.815 \\
\hline Institute Straumann AG & Switzerland & 28 & 0.761 \\
\hline King Saud University & Saudi Arabia & 28 & 0.761 \\
\hline Japan Society for the Promotion of Science (JSPS) & Japan & 25 & 0.679 \\
\hline University of Zurich & Switzerland & 22 & 0.598 \\
\hline
\end{tabular}

changes following single-tooth extraction: A clinical and radiographic 12-month prospective study." [18] in International Journal of Periodontics \& Restorative Dentistry received the highest citations (924 times) with an average citation of 51.33 times per year.

\section{DISCUSSION}

The present study assessed scientific publications pertaining to digital implantology in the last 30year period (1990-2019). Upward trends in this field were demonstrated by most bibliometric indicators. These findings could provide a self-evaluation for the dental community and be valuable to editors and publishers of implant-related journals. Regarding the countries, around $73 \%$ of the articles (2672) in this field came from these top 10 productive countries. The United States and Germany were the most productive countries in this field, which is in agreement with a similar bibliometric study for the whole of implantology [14]. Besides the quantity of publications in a country, the total citations and $\mathrm{H}$-index may represent its quality of publications as well as academic impact. The United States and Germany also ranked 1st and 2nd. Switzerland was 6 th when ranked according to the quantity of publications, but 3th for citations and 3th for $\mathrm{H}$-index. The most active authors are renowned specialists in implant dentistry linked to universities. On the list of the top 10 scholars, five of the top 10 productive authors came from Switzerland, followed by two from the United States, two from Belgium, and one from the Netherlands. Jacobs R. from the Catholic University of Leuven was the most productive author; also, this institution was a leader in this field. Three out of 10 top organizations were from Switzerland, two were from the United States, two were from Korea, the rest three were from Brazil, Belgium, Saudi Arabia. This shows that digital implantology is a subject of interest in many different countries. The University of Bern was the leading organization in digital implant dentistry research concerning the quantity of publications, citations, and $\mathrm{H}$-index. Unlike other medical areas where most of the studies were supported by the government, digital implant dentistry research was also supported by commercial organizations, and four of the top 15 active funding agencies were well-known dental implant companies and institutes. In this field, research teams worked closely with an industrial partner as they needed the expertise of engineering and precise manufacturing. At the same time, companies need researchers to test new digital products for marketing and sales. Top researchers from the top institutions can be good candidates for partnerships and may also have the priority for more investments and grants.

When it came to the analysis by journal, the articles included in this study were published in 151 journals. Around half of the articles were published in the top 10 journals, and eight of which are based in the United States. Clinical Oral Implants Research, The International Journal of Oral \& Maxillofacial Implants, Journal of Prosthetic Dentistry, and Clinical Implant Dentistry and Related Research published most studies on digital implantology. Future discoveries in digital implant dentistry are likely to be published in the aforementioned journals. Subsequently, researchers may pay more attention to studies reported by these journals. Regarding the keywords in this field, the topics can be mainly divided into five groups. In the cluster related totheaccuracy ofdigital technology, the paper "Digital vs. conventional implant impressions: efficiency outcomes" [19] was most cited with 125 
ITable 5. Top 10 cited articles in digital implantology.

\begin{tabular}{|c|c|c|c|c|c|}
\hline Title & Authors & Journal & Year & $\begin{array}{c}\text { Total } \\
\text { Citations }\end{array}$ & $\begin{array}{l}\text { Citations } \\
\text { per year }\end{array}$ \\
\hline $\begin{array}{l}\text { Bone healing and soft tissue contour } \\
\text { changes following single-tooth extraction: } \\
\text { A clinical and radiographic 12-month } \\
\text { prospective study. }\end{array}$ & $\begin{array}{l}\text { Schropp L, Wenzel A, } \\
\text { Kostopoulos L, et al. }\end{array}$ & $\begin{array}{l}\text { Int J Periodontics } \\
\text { Restorative Dent. }\end{array}$ & 2003 & 924 & 51.33 \\
\hline $\begin{array}{l}\text { A new volumetric CT machine for dental } \\
\text { imaging based on the cone-beam } \\
\text { technique: preliminary results. }\end{array}$ & $\begin{array}{l}\text { Mozzo P, Procacci C, } \\
\text { Tacconi A, et al. }\end{array}$ & Eur Radiol. & 1998 & 635 & 27.61 \\
\hline $\begin{array}{l}\text { Clinical applications of cone-beam } \\
\text { computed tomography in dental practice. }\end{array}$ & $\begin{array}{l}\text { Scarfe WC, Farman } \\
\text { AG, Sukovic P. }\end{array}$ & J Can Dent Assoc. & 2006 & 593 & 39.53 \\
\hline $\begin{array}{l}\text { Cone-beam computerized tomography } \\
(\mathrm{CBCT}) \text { imaging of the oral and } \\
\text { maxillofacial region: A systematic review of } \\
\text { the literature. }\end{array}$ & $\begin{array}{l}\text { De Vos W, } \\
\text { Casselman J, } \\
\text { Swennen GRJ. }\end{array}$ & J Oral Maxillofac Surg. & 2009 & 397 & 33.08 \\
\hline Bone augmentation techniques. & $\begin{array}{l}\text { McAllister BS, } \\
\text { Haghighat } \mathrm{K} \text {. }\end{array}$ & J Periodontol. & 2007 & 376 & 26.86 \\
\hline The future of dental devices is digital. & van Noort R. & Dent Mater. & 2012 & 367 & 40.78 \\
\hline $\begin{array}{l}\text { Crestal bone changes around titanium } \\
\text { implants. A radiographic evaluation of } \\
\text { unloaded nonsubmerged and submerged } \\
\text { implants in the canine mandible. }\end{array}$ & $\begin{array}{l}\text { Hermann JS, } \\
\text { Cochran DL, } \\
\text { Nummikoski PV, et al. }\end{array}$ & $J$ Periodontol. & 1997 & 317 & 13.21 \\
\hline $\begin{array}{l}\text { Analysis of the accuracy of linear } \\
\text { measurements obtained by cone beam } \\
\text { computed tomography (CBCT-NewTom). }\end{array}$ & $\begin{array}{l}\text { Lascala C, Panella J, } \\
\text { Marques MM. }\end{array}$ & $\begin{array}{l}\text { Dentomaxillofac. } \\
\text { Radiol. }\end{array}$ & 2004 & 305 & 17.94 \\
\hline $\begin{array}{l}\text { Accuracy of implant placement with a } \\
\text { stereolithographic surgical guide. }\end{array}$ & $\begin{array}{l}\text { Sarment DP, } \\
\text { Sukovic P, } \\
\text { Clinthorne N. }\end{array}$ & $\begin{array}{l}\text { Int J Oral Maxillofac } \\
\text { Implants. }\end{array}$ & 2003 & 273 & 15.17 \\
\hline $\begin{array}{l}\text { Bone classification: an objective scale of } \\
\text { bone density using the computerized } \\
\text { tomography scan. }\end{array}$ & Norton MR, Gamble C. & Clin Oral Implants Res. & 2001 & 250 & 12.50 \\
\hline
\end{tabular}

citations. For treatment outcome, "Bone healing and soft tissue contour changes following single-tooth extraction: a clinical and radiographic 12-month prospective study" [18] with 924 citations was the most cited one. In this study, cast and model scanner were used to evaluate the change of soft tissue contour. Recently, clinical studies using intraoral scanner to capture tissue contour were more often published [20]. In the third cluster of implant planning and placement, the most cited paper with 593 citations was "Clinical applications of cone-beam computed tomography in dental practice" [21], which reinforced that $C B C T$ played a vital role in the progress of digital implant dentistry. For implant stability and biomechanics, "Influence of cortical bone thickness and implant length on implant stability at the time of surgery-clinical, prospective, biomechanical, and imaging study" [22] had 179 citations. Regarding the trend of research topics, the most frequently used keywords in digital implantology research papers and their main year when they were published were: digital subtraction radiography, diagnosis, panoramic radiography (before 2010), $\mathrm{CT}$, osseointegration, bone, resonance frequency analysis (2011), placement, surgery, surgical guide, in-vitro, biomechanics (2012), accuracy, followup, interface, finite-element-analysis, restorations (2013), augmentation, soft tissue, (2014), CAD/CAM, intraoral impression, abutment, fixed dental prostheses, zirconia, guided surgery (2015), floor elevation (2016), digital workflow, 3D printing, digital impression (2017). This suggests that the emphasis of digital implant dentistry research responds to the prosthetic field and digital workflow that is very new to researchers. Supplementary large-scale clinical studies on different digital systems and different digital workflows will be vital to better utilize these processes and/or understand the potential of the digital technology.

\section{Limitations}

The publications included in this study were screened and selected from the Web of Science database, and the analysis was relatively objective 
and comprehensive. However, it should be noted that studies published in 2020 were not included in the present study and digital technologies are a very dynamic area in implant dentistry. Therefore, future research may soon become necessary with the latest published studies.

Besides, in the Web of Science, the number of publications for each author was counted regardless of the position of the author.

For example, a document with five authors is counted once for each author.

Therefore, a potential overlap in the number of publications assigned for each author may happen. The same applies to data regarding the most active countries and organizations.

\section{REFERENCES}

1. Buser D, Sennerby L, De Bruyn H. Modern implant dentistry based on osseointegration: 50 years of progress, current trends and open questions. Periodontol 2000. 2017;73(1):7-21. doi: $10.1111 /$ prd.12185.

[Full text links] [CrossRef] [PubMed] Google Scholar Scopus 2. Joda T, Ferrari M, Gallucci GO, et al. Digital technology in fixed implant prosthodontics. Periodontol 2000. 2017;73(1):178-192. doi: $10.1111 /$ prd.12164.

[Full text links] [CrossRef] [PubMed] Google Scholar Scopus 3. Zhang Y, Tian J, Wei D, et al. Quantitative clinical adjustment analysis of posterior single implant crown in a chairside digital workflow: a randomized controlled trial. Clin Oral Implants Res. 2019;30(11):1059-1066. doi: 10.1111/clr.13519.

[Full text links] [CrossRef] [PubMed] Google Scholar Scopus 4. Li J, Chen Z, Dong B, et al. A digital workflow with computerassisted implant planning for fabricating an impression splinting framework and custom tray for multiple implants. J Prosthet Dent. 2019 Nov 25. pii: S0022-3913(19)30585-2. doi: 10.1016/j. prosdent.2019.08.021.

[Full text links] [CrossRef] [PubMed] Google Scholar Scopus 5. Hämmerle CHF, Cordaro L, van Assche N, et al. Digital technologies to support planning, treatment, and fabrication processes and outcome assessments in implant dentistry. Summary and consensus statements. The 4th EAO consensus conference 2015. Clin Oral Implants Res. 2015;26 Suppl 11:97-101. doi: $10.1111 / \mathrm{clr} .12648$.

[Full text links] [CrossRef] [PubMed] Google Scholar Scopus 6. Bornstein MM, Horner K, Jacobs R. Use of cone beam computed tomography in implant dentistry: current concepts, indications and limitations for clinical practice and research. Periodontol 2000. 2017;73(1):51-72. doi: 10.1111/prd.12161. [Full text links] [CrossRef] [PubMed] Google Scholar Scopus 7. Mizumoto RM, Yilmaz B. Intraoral scan bodies in implant dentistry: a systematic review. J Prosthet Dent. 2018;120(3):343352. doi: 10.1016/j.prosdent.2017.10.029.

[Full text links] [CrossRef] [PubMed] Google Scholar Scopus 8. Li J, Chen Z, Wang M, et al. Dynamic changes of peri-implant soft tissue after interim restoration removal during a digital intraoral scan. J Prosthet Dent. 2019;122(3):288-294. doi: 10.1016/j.prosdent.2018.07.020.

[Full text links] [CrossRef] [PubMed] Google Scholar Scopus 9. Flügge T, Ludwig U, Hövener JB, et al. Virtual implant planning and fully guided implant surgery using magnetic resonance imaging - proof of principle. Clin Oral Implants Res. 2020 Feb 27. doi: $10.1111 /$ clr.13592.

[Full text links] [CrossRef] [PubMed] Google Scholar Scopus 10. Bhaskar V, Chan HL, MacEachern M, Kripfgans OD. Updates on ultrasound research in implant dentistry: a systematic review of potential clinical indications. Dento Maxillo Facial Radiol. 2018; 47(6):20180076 doi: 10.1259/dmfr.20180076.

[Full text links] [CrossRef] [PubMed] Google Scholar Scopus 11. Chan HL, Sinjab K, Li J, et al. Ultrasonography for noninvasive and real-time evaluation of peri-implant tissue dimensions. J Clin Periodontol. 2018;45(8):986-995. doi: 10.1111/jcpe.12918. [Full text links] [CrossRef] [PubMed] Google Scholar Scopus

\section{CONCLUSION}

The present study showed significant growth in the literature regarding digital implantology research in the last decade. The United States was in the leading position. Digital workflow, digital impression, and 3D printing are the latest popular topics.

\section{CONFLICT OF INTEREST}

Authors declare no conflict of interest related to this manuscript.

\section{AUTHOR CONTRIBUTIONS}

ZC, JL, and HLW: contributed to the conception of the work. ZC and $\mathrm{JL}$ : collected and analyzed the data, wrote the manuscript. CYL and HLW: critically revised the manuscript.

12. Jayaratne YSN, Zwahlen RA. The evolution of dental journals from 2003 to 2012: a bibliometric analysis. PloS One. 2015;10(3):e0119503. doi: 10.1371/journal.pone.0119503. [Free text links] ] [CrossRef] [PubMed] Google Scholar Scopus 13. Pommer B, Valkova V, Ubaidha Maheen C, et al. Scientific interests of 21 st century clinical oral implant research: topical trend analysis. Clin Implant Dent Relat Res. 2016;18(4):850-856. doi: $10.1111 /$ cid.12371.

[Full text links] [CrossRef] [PubMed] Google Scholar Scopus 14. Tarazona B, Vidal-Infer A, Alonso-Arroyo A. Bibliometric analysis of the scientific production in implantology (2009-2013). Clin Oral Implants Res. 2017;28(7):864-870. doi: 10.1111/clr.12891. [Full text links] [CrossRef] [PubMed] Google Scholar 15. Gao Y, Wang Y, Zhai X, et al. Publication trends of research on diabetes mellitus and T cells (1997-2016): A 20-year bibliometric study. PloS One. 2017;12(9):e0184869. doi: 10.1371/journal. pone.0184869.

[Full text links] [CrossRef] [PubMed] Google Scholar

16. Hirsch JE. An index to quantify an individual's scientific research output. Proc Natl Acad Sci U S A. 2005;102(46):1656916572. doi: $10.1073 /$ pnas.0507655102.

[Full text links] [CrossRef] [PubMed] Google Scholar Scopus 17. van Eck NJ, Waltman L. Software survey: VOSviewer, a computer program for bibliometric mapping. Scientometrics. 2010;84(2):523-538. doi: 10.1007/s11192-009-0146-3.

[Full text links] [CrossRef] [PubMed] Google Scholar Scopus 18. Schropp L, Wenzel A, Kostopoulos L, Karring T. Bone healing and soft tissue contour changes following single-tooth extraction: a clinical and radiographic 12-month prospective study. Int J Periodontics Restorative Dent. 2003;23(4):313-323. [PubMed] Google Scholar Scopus

19. Lee SJ, Gallucci GO. Digital vs. conventional implant impressions: efficiency outcomes. Clin Oral Implants Res. 2013;24(1):111-115. doi: 10.1111/j.1600-0501.2012.02430.x. [Full text links] [CrossRef] [PubMed] Google Scholar Scopus 20. van Nimwegen WG, Raghoebar GM, Zuiderveld EG, et al. Immediate placement and provisionalization of implants in the aesthetic zone with or without a connective tissue graft: A 1 -year randomized controlled trial and volumetric study. Clin Oral Implants Res. 2018;29(7):671-678. doi: 10.1111/clr.13258.

[Full text links] [CrossRef] [PubMed] Google Scholar Scopus 21. Scarfe WC, Farman AG, Sukovic P. Clinical applications of cone-beam computed tomography in dental practice. J Can Dent Assoc. 2006;72(1):75-80.

[Full text links] [CrossRef] [PubMed] Google Scholar Scopus 22. Miyamoto I, Tsuboi Y, Wada E, et al. Influence of cortical bone thickness and implant length on implant stability at the time of surgery--clinical, prospective, biomechanical, and imaging study. Bone. 2005;37(6):776-780. doi: 10.1016/j.bone.2005.06.019. [Full text links] [CrossRef] [PubMed] Google Scholar Scopus 


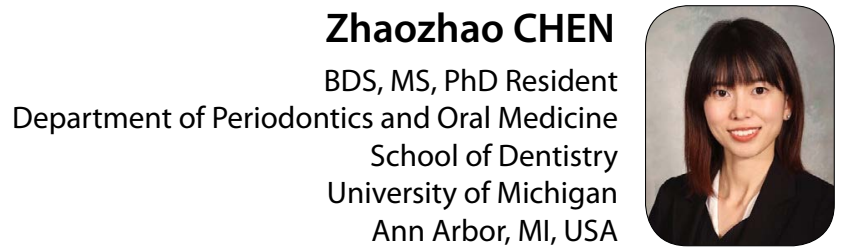

Zhaozhao Chen is a Periodontics resident at the School of Dentistry, University of Michigan, Ann Arbor, MI, USA. She earned her BDS (2013), MS (2015), and PhD (2019) degree from the West China School of Stomatology, Sichuan University, China. Her current research focuses on the application of digital technology in implant dentistry and the development of regenerative biomaterials in ridge augmentation.

\section{Questions}

1. The following are considered as the latest popular topics in digital implant dentistry, with one exception?

口a. Digital workflow;

ab. Digital impression;

Dc. 3D printing;

ad. Resonance frequency analysis.

2. Which of the following is increasingly being tested in research for the assessment of implant treatment outcome?

口a. CBCT;

b. Optical scanner;

ac. Ultrasonography;

ad. All above.

\section{Which of the following is a bibliometric indicator?}

a. Number of publications;

ab. Number of citations;

ac. H-index;

ad. All above.

4. Which one indicates that a scholar (or country or organization) has published $\mathrm{H}$ papers and each of which has been cited in other publications at least $\mathrm{H}$ times?

Da. Impact factor (IF);

ab. H-index;

ac. Citation index;

ad. Hotspot analysis. 